NBER WORKING PAPER SERIES

\title{
EFFECTS OF VENUE-SPECIFIC STATE CLEAN INDOOR AIR LAWS ON SMOKING-RELATED OUTCOMES
}

\author{
Marianne P. Bitler \\ Christopher Carpenter \\ Madeline Zavodny \\ Working Paper 15229 \\ http://www.nber.org/papers/w15229
}

\author{
NATIONAL BUREAU OF ECONOMIC RESEARCH \\ 1050 Massachusetts Avenue \\ Cambridge, MA 02138 \\ August 2009
}

We thank Gary Giovino and colleagues at the Roswell Park Cancer Institute for sharing the ImpacTeen Tobacco Control Policy Data, and we thank Jaime Chriqui for detailed discussions about how the laws were coded. For generous financial support, Carpenter thanks the UC Institute of Labor and Employment and the Paul Merage School of Business at UC Irvine, and Bitler and Zavodny thank the National Institutes of Health (CDC/NIOSH OH008244). Results do not imply their endorsement; all errors are our own. The views expressed herein are those of the author(s) and do not necessarily reflect the views of the National Bureau of Economic Research.

NBER working papers are circulated for discussion and comment purposes. They have not been peerreviewed or been subject to the review by the NBER Board of Directors that accompanies official NBER publications.

(C) 2009 by Marianne P. Bitler, Christopher Carpenter, and Madeline Zavodny. All rights reserved. Short sections of text, not to exceed two paragraphs, may be quoted without explicit permission provided that full credit, including $(\mathcal{C}$ notice, is given to the source. 
Effects of Venue-Specific State Clean Indoor Air Laws on Smoking-Related Outcomes Marianne P. Bitler, Christopher Carpenter, and Madeline Zavodny

NBER Working Paper No. 15229

August 2009

JEL No. I1

\begin{abstract}
$\underline{\text { ABSTRACT }}$
A large literature has documented relationships between state clean indoor air laws (SCIALs) and smoking-related outcomes in the US. These laws vary within states over time and across venues such as schools, government buildings, and bars. Few studies, however, have evaluated whether the effects of SCIALs are plausibly concentrated among workers who should have been directly affected because they worked at locations covered by the venue-specific restrictions. We fill this gap in the literature using data on private sector workers, government employees, school employees, eating and drinking place workers, and bartenders from the 1992-2007 Tobacco Use Supplements to the Current Population Survey. Our quasi-experimental models indicate robust effects of SCIALs restricting smoking in bars: these laws significantly increased the presence of workplace smoking restrictions as reported by bartenders and reduced the fraction of bartenders who smoke. We do not, however, find that SCIALs in private workplaces, government workplaces, schools, or restaurants increased the presence of workplace smoking restrictions among groups of workers working in venues covered by these laws. This suggests that the smoking reductions associated with SCIALs in previous research are unlikely to have been directly caused by effects of workplace smoking restrictions on workers.
\end{abstract}

Marianne P. Bitler

Department of Economics

University of California, Irvine

3151 Social Science Plaza

Irvine, CA 96297

and NBER

mbitler@uci.edu

Christopher Carpenter

University of California, Irvine

The Paul Merage School of Business

$428 \mathrm{SB}$

Irvine, CA 92697-3125

and NBER

kittc@uci.edu
Madeline Zavodny

Agnes Scott College

141 E. College Ave.

Decatur, GA 30030

mzavodny@agnesscott.edu 


\section{Effects of Venue-Specific State Clean Indoor Air Laws on Smoking-Related Outcomes}

\section{INTRODUCTION}

A large literature in economics and public health has examined the ability of public policies to influence smoking and smoking-related outcomes such as exposure to secondhand smoke (SHS). In particular, researchers and policymakers have increasingly focused on effects of state clean indoor air laws (henceforth SCIALs), policies that prohibit or restrict smoking in various venues such as private workplaces, schools, and restaurants. Numerous studies have shown that individuals who live in states with stronger clean indoor air policies covering more venues have better smoking-related outcomes than otherwise similar individuals in states with clean indoor air policies that are less strict or cover fewer venues (e.g., Emont et al., 1993; Wasserman et al., 1991; and Chaloupka, 1992). A smaller body of more recent research - mainly by economistshas shown that some of these relationships for smoking-related outcomes are robust to including unrestricted state and year fixed effects in the models, thus identifying the effects of SCIALs from within-state changes in the number or restrictiveness of clean indoor air laws (e.g., Tauras, 2006; Yurkeli and Zhang, 2000).

In this paper we provide new evidence on the effects of SCIALs using the 1992-2007 Tobacco Use Supplements to the Current Population Survey (CPS TUS). These data provide large samples of individual-level responses to questions about employment, workplace smoking restrictions, and own-smoking outcomes. To the CPS TUS data we match detailed policy information on the presence and strength of SCIALs for 12 separate venues (such as schools, government workplaces, and bars) using Robert Wood Johnson's ImpacTeen database.

Together, the CPS TUS microdata and state policy data allow us to make two important contributions to the existing literature. First, we are able to make explicit use of the venue- 
specific nature of clean indoor air laws by identifying groups of workers (through combinations of class of worker, occupation, and industry codes) who should have been directly affected by a venue-specific restriction while at work. For example, laws restricting smoking in schools should disproportionately affect smoking behaviors among teachers and other school employees, while policies banning smoking in bars should have relatively strong effects for bartenders.

Second, we are able to test directly for "compliance effects" of venue-specific SCIALs: whether the state laws changed actual worksite smoking policies as reported by workers in the CPS TUS data. Most existing research relates clean indoor air laws to smoking outcomes, but the compliance effect (whether the laws actually changed smoking restrictions in practice) is a key necessary condition for interpreting observed reductions in smoking associated with clean indoor air policy as being attributable to exposure to tougher restrictions at work (Carpenter 2009, forthcoming). ${ }^{1}$

We combine these two features of the CPS TUS data below to test whether, say, SCIALs restricting smoking in government workplaces affected the worksite smoking policies and smoking-related behaviors reported by government workers. Together, these tests allow us to provide important evidence on whether and how venue-specific SCIALs affect outcomes. We estimate straightforward models of own reports of official worksite smoking restrictions and smoking behavior. In addition to controls for individual and state characteristics, all of our models also include fixed effects for the CPS TUS survey month and year as well as unrestricted state dummies; thus, our estimates of the effects of the venue-specific SCIALs are identified from the numerous changes in venue-specific restrictions within states over time.

\footnotetext{
${ }^{1}$ Below, we discuss several reasons why changes in SCIALs might not directly lead to commensurate changes in actual worksite smoking policies.
} 
To preview, we find robust evidence that state laws restricting smoking in bars significantly increased the prevalence of bartender-reported worksite smoking restrictions and reduced the likelihood of smoking among bartenders. We do not, however, find robust effects of SCIALs that cover private workplaces, government buildings, schools, or restaurants on outcomes for workers who should have been most directly affected by those policies (private sector workers, government workers, school employees, and workers in eating and drinking places, respectively). This suggests that any effects of SCIALs on smoking-related outcomes in previous research are unlikely to have been caused by workers' direct exposure to tougher worksite restrictions.

The remainder of the paper proceeds as follows: Section 2 describes the relevant literature and provides a conceptual framework. Section 3 describes the CPS TUS microdata and ImpacTeen policy data and outlines the empirical approach. Section 4 presents the main results, and Section 5 concludes.

\section{CONCEPTUAL FRAMEWORK}

There are several mechanisms through which workplace SCIALs can be related to smoking restrictions and smoking-related outcomes. First, there is a direct causal link: states adopt laws stating that workplaces must restrict smoking, workplaces comply with the laws and implement restrictions, and people working at those places either stop smoking or reduce their cigarette consumption. $^{2}$

SCIALs and workplace smoking restrictions can also affect smoking-related outcomes indirectly. If peer effects are important to smoking behaviors (as suggested by Cutler and

\footnotetext{
${ }^{2}$ Evans, Farelly, and Montgomery (2002) is among the first studies to look at the effect of employer-instituted work bans on smoking behaviors but does not consider the laws evaluated here.
} 
Glaeser, 2007 and others) workplace smoking restrictions may spill over to people other than workers at venues that restrict smoking. For example, both spouses may quit smoking after one spouse's workplace restricts smoking. Another possibility is that workplace smoking restrictions affect customers' smoking. This mechanism is most plausible for restrictions on smoking in public workplaces, such as bars and restaurants. If there are indirect peer and customer effects, venue-specific workplace SCIALs may reduce smoking among individuals besides the workers at the specific venues to which the SCIALs apply.

Changes in social norms and the acceptability of smoking may be a common determinant of SCIAL adoption, workplace smoking restrictions, and reduced smoking. Models that do not account for changes in social norms thus might mistakenly suggest a causal relationship between SCIALs, workplace smoking restrictions, and smoking because of omitted variable bias. ${ }^{3}$

In addition, passage of SCIALs might not lead to commensurate changes in actual worksite smoking policies. Some employers may purposely defy the law because of concerns about negative effects on their businesses. ${ }^{4}$ Other employers may not be well-informed about laws since state laws vary dramatically as to which venues are actually subject to SCIALs and how stringent such laws are. Finally, some employers may have already implemented restrictions without having been compelled to do so.

Previous research on effects of venue-specific restrictions is unable to shed light on the mechanisms through which SCIALs affect smoking. Indeed, earlier studies reached mixed conclusions as to whether venue-specific SCIALs affect smoking. Taurus (2006) finds that restrictions on smoking at shopping malls have a larger negative effect on smoking among the

\footnotetext{
${ }^{3}$ We address this concern by controlling for anti-smoking sentiment (DeCicca et al., 2008) in robustness tests. Our results are not affected.

${ }^{4}$ There are many newspaper accounts of bar and restaurant owners, for example, actively defying smoking bans. We unfortunately do not have data on the penalties for noncompliance with SCIALs, which typically include fines (on the order of hundreds to thousands of dollars) for each violation.
} 
general population than restrictions at private workplaces or restaurants, while restrictions at health facilities are positively associated with smoking intensity. Taurus (2004) reports a positive relationship between smoking among the general population and restrictions at government workplaces but a negative relationship for restrictions at hotels and restaurants. Adda and Cornaglia (2009, forthcoming) find that cotinine levels among households with a smoker are positively related to smoking restrictions at restaurants and bars, likely due to displacement of smoking from those venues into homes. ${ }^{5}$ Previous studies did not directly test for compliance with worksite SCIALs or focus on smoking among workers at specific affected venues. Examining the relationship between venue-specific SCIALs, actual reported worksite smoking policies, and smoking among workers at affected venues is therefore an important exercise.

\section{METHODS}

\subsection{Data}

Our individual-level data are from the CPS TUS. These surveys have been carried out periodically since 1992 and have been used in previous research to evaluate the effects of SCIALs and other tobacco control policies (e.g., Tauras, 2006; Lovenheim, 2008). ${ }^{6}$ The data contain detailed information about smoking, demographic characteristics, and employment. Individuals who work indoors and are not self-employed report whether their workplace has any

\footnotetext{
${ }^{5}$ We do not review here a small number of public health studies that have descriptively examined a variety of outcomes for particular occupation groups relevant for our analysis. Shopland et al. (2004), for example, find that food service workers are less likely to be covered by official worksite smoking restrictions than are other workers. ${ }^{6}$ The CPS TUS was carried out 2 or 3 times in each of 7 waves: 1992-93, 1995-96, 1998-99, 2000, 2001-02, 2003, and 2006-07. Our study incorporates every survey that included information about workplace restrictions on smoking; this was not included in the 2000 CPS TUS.
} 
official restrictions on smoking in the workplace. ${ }^{7}$ We create an indicator variable equal to one if an individual reports that her worksite has any official restriction on smoking. ${ }^{8}$ Although workers' self-reports of worksite smoking restrictions are unlikely to be perfectly accurate, they are likely to be better than other measures of compliance with SCIALs. Employers, for example, could be unwilling to report non-compliance with SCIALs due to fear of sanctions; this reporting bias should be less salient for workers who do not face such liability. Moreover, if SCIALs change employer implementation of workplace smoking policies but these are not actually translated into changes in workers' perceptions of those policies, SCIALs should not be expected to affect worker outcomes. As such, worker reports provide a valuable perspective on whether, how, and to what extent SCIALs affected smoking-related outcomes.

We also use the CPS TUS data to create two variables that measure smoking-related outcomes. We classify an individual age 18 or older as a smoker if she reports that she currently smokes every day or some days. We measure smoking intensity among smokers using information on the number of days in the past 30 days a respondent reported smoking multiplied by the average number of cigarettes she reported smoking on the days she smoked. We use the natural log of this value as the dependent variable in smoking intensity models.

\footnotetext{
${ }^{7}$ The questions about workplace smoking bans were only asked of self-respondents to the smoking supplement, so we use the self-response weights to obtain population representative results. This yields a maximum of 1,133,546 observations for adults 18 and older with a valid non-zero self-response weight. We exclude observations for two reasons. The first group of 615,113 observations were out of scope for the workplace smoking policy questions (were not in the labor force or unemployed, self-employed or not working for pay, worked outdoors or in a home or in a vehicle or at varied locations). The second group had an invalid response for smoking status $(3,312$ observations), didn't know/refused/had no response to the questions about working indoors (7,682 observations), or didn't know/refused/had no response to the questions about workplace smoking bans (5,643 observations). This left our final sample of 501,796 workers with responses to the workplace smoking policy questions.

${ }^{8}$ Specifically, individuals are asked, "Does your place of work have an official policy that restricts smoking in any way?"
} 
Our data on SCIALs come from Robert Wood Johnson's ImpacTeen database. ${ }^{9}$ These data represent a comprehensive effort to track and consistently code each state's clean indoor air restrictions in 12 venues: private workplaces, government workplaces, restaurants, bars, health care facilities, public schools, private schools, shopping malls, public transit, child care centers, recreational facilities, and cultural facilities. These ratings have a couple of key advantages over other sources of information on state clean indoor air policies. First, they cover our entire sample period (1992-2007), so we can use the full CPS TUS series in our analysis. This allows us to incorporate more recent policy changes than previous work. ${ }^{10}$ Second, the ImpacTeen ratings include considerably more detail than any other tracking system of clean indoor air laws. The ImpacTeen data cover more venues than other sources of such laws, and within each venue it provides strength ratings that indicate the relative restrictiveness of each venue-specific policy on a scale of $0-3$ or $0-5$. The exact coding varies across venues, but for most venues a rating of zero indicates no restriction; a rating of one indicates a restriction that allows a separate designated smoking area; a rating of two indicates a restriction that requires a separately ventilated area; and a rating of three indicates a complete ban on smoking. ${ }^{11}$ These ratings allow us to take advantage of variation in both the strength of each policy and the specific venues covered.

\footnotetext{
${ }^{9}$ These are the ImpacTeen Tobacco Control Policy Data. A version of these data for 1991-2008 is posted on the ImpacTeen website (www.impacteen.org). We used the version as posted on their website on June 5, 2009.

${ }^{10}$ Most other sources (e.g., the National Cancer Institute's State Cancer Legislative Database (SCLD) and the American Lung Association's State Legislated Actions on Tobacco Institutions (SLATI)) stop tracking the state policies well before the end of our sample. The ImpacTeen ratings are strongly correlated with SCLD and SLATI data for the venues and time periods for which we have comparable series. The other commonly used coding is the Americans for Nonsmoker's Rights Foundation (ANRF), which passively tracks restrictions for a subset of our venues. There is a mismatch in the geography for the CPS TUS and the ANRF which precludes matching the CPS TUS to the ANRF data exactly.

${ }^{11}$ For venues which range from $0-5,5$ represents a full ban. The exceptions to these general rules can be found in Appendix B of the ImpacTeen tobacco policy codebook.
} 


\subsection{Regression model}

Our main empirical approach for evaluating the effects of SCIALs on worksite smoking restrictions and smoking behaviors is a straightforward state and year fixed effects model. Changes in outcomes for individuals in states over time coincident with policy adoption are compared with changes in outcomes for individuals in states that did not change policy. These models take the general form

$$
\left.Y_{\text {ist }}=\alpha+\beta_{1} X_{\text {ist }}+\beta_{2} Z_{\text {st }}+\beta_{3} \text { (Venue-Specific SCIAL Ratings) }\right)_{\text {st }}+S_{s}+T_{t}+\varepsilon_{\text {ist }}
$$

where $Y_{\text {ist }}$ are our various outcomes of interest for individual $i$ in state $s$ at time $t$. For

dichotomous outcomes (presence of any worksite smoking restriction and smoking) we estimate linear probability models for ease of interpretation; for smoking intensity we estimate OLS regressions with $\log$ cigarettes as the dependent variable. ${ }^{12} X_{\text {ist }}$ is a vector of individual demographic characteristics and includes sex, age and its square, marital status dummies, education dummies, race/ethnicity dummies, a dummy variable indicating residence outside a metropolitan statistical area, and dummy variables for family income. ${ }^{13} Z_{s t}$ is a vector of timevarying state characteristics and policies and includes the state unemployment rate, annual state employment growth rate, percent of population below the poverty line, and the real value of the state excise tax on a pack of cigarettes. ${ }^{14} S_{s}$ is a full set of state fixed effects and captures all time-invariant state characteristics that may impact outcomes (e.g., religiosity). $T_{t}$ is a full set of survey year and month dummies and accounts for secular changes in outcomes common to

\footnotetext{
${ }^{12}$ This follows the health economics literature which estimates two-part models of smoking participation and intensity (Cragg, 1971; Manning et al., 1981; Duan et al., 1983; Mullahy, 1998; and others). Our main results for the dichotomous outcomes are robust to using a probit model.

${ }^{13}$ Full details on our control variables can be found in the Data Appendix on the corresponding author's website.

${ }^{14}$ State excise taxes come from Orzechowski and Walker (2004) and Campaign for Tobacco Free Kids (2009). We deflate nominal variables with the personal consumption expenditures deflator from the Bureau of Economic Analysis. State unemployment rates are from the Bureau of Labor Statistics. State employment growth rates are based on Bureau of Economic Analysis employment levels. State poverty statistics are from the U.S. Census Bureau.
} 
everyone in the sample in each year or month (e.g., season). Standard errors are clustered at the state level (Bertrand, Duflo, and Mullainathan, 2004).

Venue-Specific SCIAL Ratings st $_{\text {is }}$ a vector of 12 venue-specific restrictions that vary at the state/year level. For our baseline specification, these ImpacTeen ratings range from 0-3 for all venues except public and private schools, child care centers, recreational facilities, cultural facilities, and public transit (which range from $0-5) .{ }^{15}$

\subsection{Venues}

One of our key contributions is to evaluate the effects of venue-specific SCIALs among groups of workers likely to have been directly affected by such laws. There are five venues for which we can reasonably identify workers likely to have been affected by venue-specific SCIALs: private sector workplaces, government workplaces, public and private schools, restaurants, and bars. We identify workers in these venues based on occupation, industry, or class of worker. Specifically, we define private and government sector workers based on the CPS class of worker code. School employees are defined using the CPS industry codes for elementary and secondary schools. We identify restaurant workers as those individuals employed at eating and drinking place places. We use bartenders in eating and drinking places (defined using CPS occupation and industry codes) as individuals who should be disproportionately likely to be affected by SCIALs covering bars. We focus on bar SCIALs when examining bartenders because a large share (37\%) of bartenders work in stand-alone bars

\footnotetext{
${ }^{15}$ We also estimated variations of this model including only strength-weighted measures of SCIALs for venues specific to a group of workers, as well as regressions that use a simple strength-weighted index of all restrictions instead of separate controls for each venue-specific restriction. In this model, the vector of Venue-Specific SCIAL Ratings is replaced by a single Strength-Weighted SCIAL Index, where the index variable equals the simple sum of the 12 venue-specific values. The index can range from 0 to 48; similar indices have been used in previous research.
} 
rather than in restaurants. ${ }^{16}$ Bartenders are only a small fraction $(5 \%)$ of employees at eating and drinking places, however, so we focus on restaurant SCIALs when examining all workers at eating and drinking places.

We are not able to create groups of workers who should have been relatively affected by SCIALs that apply to the other venues included in the ImpacTeen data. These venues are: recreational facilities, cultural facilities, public transit, health care facilities, and shopping malls. This is primarily because there is no clear way of identifying employed individuals in these worksites (e.g., it is impossible to distinguish people who work at a shopping mall from those who work at a stand-alone store in the CPS data).

\section{RESULTS}

\subsection{Descriptive Statistics}

Since all of our models include state and time fixed effects, identification of the effects of venuespecific SCIALs requires within-state changes in venue-specific restrictions. Table I shows that such variation exists, particularly in recent years. For each venue tracked in the ImpacTeen data we present the annual average across all states for each venue-specific strength-weighted index during 1992-2007, weighted using the sum of the CPS TUS populations for each state. The possible values for the specific venues shown in the other columns can range from 0-3 (or 0-5 for public schools, private schools, child care centers, recreational facilities, cultural facilities, and public transit).

\footnotetext{
${ }^{16}$ Authors' calculation from the 2003-07 CPS TUS. We can only separately identify bars (drinking places) from restaurants (eating places) beginning with the 2003 CPS TUS (the first sample year with updated 2000 Census industry codes). Throughout, we focus on bartenders in eating and drinking places. Thus, the bartenders we consider are a perfect subset of the group of eating and drinking place workers we consider. Bartender is the most common occupation among workers in bars ( $49 \%$ of the bar workforce).
} 
Several patterns are apparent in Table I. First, clean indoor air restrictions were already widespread at the beginning of our sample period: by 1992, each of the 12 venues was already covered somewhere in the U.S. by at least some type of restriction. Second, there is substantial variation in SCIALs across venues. In 1992, for example, bars and shopping malls had considerably more limited coverage than health care facilities and public schools. Third, there have been numerous changes in SCIALs over time and especially since 2000 . The venuespecific indexes all increased substantially over time. Finally — and most importantly for our identification strategy — the timing and magnitude of the changes in SCIALs varies across venues. Although Table I shows that the late 1990s were a general period of stagnation with respect to strengthened SCIAL restrictions, there are numerous instances where year to year changes in one venue-specific index do not exactly track changes in other venues, particularly in the latter part of our sample period. This differential timing of adoption of venue-specific restrictions forms the basis for identification of our fixed effects models.

Table II presents key descriptive statistics on smoking outcomes, SCIAL coverage, and workplace smoking restrictions for the 1992-2007 CPS TUS data. Each column reflects a separate group of workers. Means for private sector workers, government sector workers, school employees, eating and drinking place workers, and bartenders are reported in Columns 1-5, respectively. There are large differences in smoking rates and official workplace smoking restrictions for different groups of workers. While $34 \%$ of all workers in eating and drinking places and $51 \%$ of bartenders in those places report being a current smoker, only $10 \%$ of school employees and $15 \%$ of government workers smoke. Workplace smoking restrictions also vary substantially across the different types of workers: while only $77 \%$ of all eating and drinking place workers report the presence of any smoking restriction at work, over $96 \%$ of school 
employees report a restriction. Notably, only about $43 \%$ of bartenders in eating and drinking places report the presence of any workplace smoking restriction. The large difference between the fractions of all eating and drinking place workers and of bartenders reporting workplace smoking restrictions (along with the fact that many bartenders work in drinking places, but bartenders are a small share of eating place workers) supports our focus on restaurant SCIALs for the former group and bar SCIALs for the latter group.

\subsection{Venue-Specific SCIAL Effects on Compliance}

We first examine worksite compliance with SCIALs in order to determine whether laws affect actual clean indoor air policies. We present these results in Table III. Each column presents the coefficients on the 12 SCIALs from a separate estimation of equation (1) for each of the relevant groups of workers: private sector workers, government sector workers, school employees, all workers in eating/drinking places, and bartenders in eating/drinking places. The dependent variable is an indicator equal to one for individuals who report that their worksite has an official policy that restricts smoking. The sample is restricted to non self-employed individuals who work indoors, the group asked about workplace smoking policy. The regressions include all the control variables described above; those coefficients are not shown here but are available on request.

The results in Table III provide very limited evidence of compliance effects. In the sample of private sector workers in Column 1, we fail to find a significant relationship between reports of official smoking restrictions at work and the venue-specific restriction that should have mattered most to those workers - restrictions on smoking in private workplaces. Column 2 of Table III reports the results for government workers. Again, we find no effect of SCIALs for 
government workplaces, which should be particularly salient for these workers if the SCIALs truly affect official smoking policies. Column 3 of Table III reports results for individuals employed at K-12 schools. Restrictions on smoking at schools should be particularly relevant for these individuals if the laws truly change worksite policies. We find little evidence, however, that individuals employed at schools are more likely to report the presence of an official worksite restriction when tougher SCIALs covering either public or private schools are adopted. Both coefficients are small and statistically indistinguishable from zero. ${ }^{17}$ Results for all workers in eating and drinking places are in Column 4. SCIALs covering restaurants should have particularly strong effects on reported worksite restrictions for these workers, but the relevant coefficient is small and statistically insignificant.

The one venue where we do find evidence of compliance effects is bars. Results for bartenders in eating and drinking places are in Column 5; as noted above, SCIALs covering bars should be the most relevant for these workers. There is a significant positive association between bar SCIALs and the probability a bartender reports her workplace has an official smoking restriction. ${ }^{18}$ Specifically, a one unit increase in a state law restricting smoking in bars significantly increases the likelihood that a bartender reports an official workplace restriction by 11.3 percentage points. ${ }^{19}$ Given that the average strength-weighted SCIAL variable for bars increased by about 1.17 units over our sample period, we estimate that SCIALs covering bars

\footnotetext{
${ }^{17}$ About $84 \%$ of the school employees in the CPS TUS work in public schools.

${ }^{18}$ In results not reported here but available upon request, this compliance effect for bartenders is robust to using a probit regression to model the dichotomous outcome reflecting the presence of any workplace policy. The compliance effect for bartenders also is robust to controlling for state preemption of SCIALs covering bars as coded in the ImpacTeen database. State preemption laws generally restrict the ability of localities to adopt clean indoor air policies that are more stringent than the state law. Finally, the compliance effect for bartenders is robust to controlling for anti-smoking sentiment (DeCicca et al., 2008) for the period through 2003 (when that variable is available).

${ }^{19}$ Over our sample period, 17 states passed or strengthened SCIALs covering bars, 14 during the period 2003-07.
} 
increased official workplace smoking restrictions by about 13.2 percentage points $\left(1.17^{*} 11.3\right)$, which is approximately $31 \%$ relative to the sample mean (13.2/42.6).

We further examine the robustness of the compliance effect for bartenders in Table IV. Column 1 of Table IV simply reproduces the baseline estimate on the bar SCIAL from Column 5 of Table III (the model also includes separate controls for each of the 11 other venue-specific SCIALs). In Columns 2 and 3, we show that the compliance effect for bartenders is robust to addressing concerns about policy collinearity (i.e., states sometimes include SCIALs covering multiple venues within the same piece of legislation) among the venue-specific SCIALs. Specifically, in Column 2 we simply exclude the controls for the 11 other venue-specific SCIALs and assume that the bar SCIAL is the only one that should directly affect compliance among bartenders. This model returns an estimate very close to that in the main specification of Column 1. In Column 3 we control for the bar SCIAL but include a summary measure that equals the sum of the strength-weighted SCIALs in the 11 other venues (instead of measuring them separately, as in Column 1, or excluding them, as in Column 2). This is an alternative way to control for the broader clean indoor air policy environment while at the same time alleviating the challenge of estimating 12 distinct SCIAL coefficients. Importantly, we continue to find a strong compliance effect of bar SCIALs on bartenders, and the coefficient on the summary index variable for the 11 other SCIALs is small and statistically insignificant. In Column 4 of Table IV we return to the baseline specification with each of the 12 SCIALs entered separately, but we add controls for linear state-specific time trends. Again, we find that the compliance effect of SCIALs covering bars is robust. Finally, in Columns 5 and 6 of Table IV we consider alternative measures of compliance. In Column 5, the outcome is an indicator equal to one if the bartender reports that there is a complete ban on smoking in work areas at the workplace. In Column 6, the 
outcome is an indicator equal to one if the bartender reports that there is a complete ban on smoking in public areas at the workplace (such as lobbies, restrooms, and lunch rooms). ${ }^{20}$ Both models estimate the baseline specification as in Column 1 but with a different dependent variable. These alternative measures of compliance show strong evidence that SCIALs covering bars increased a variety of measures of workplace smoking restrictions among bartenders. These additional results increase our confidence in the compliance effects for bartenders.

We also performed a similar set of robustness checks for the other groups of workers, since multicollinearity in the venue-specific SCIALs is a more general concern. First, we performed a factor analysis similar to DeCicca et al. (2008) to isolate the true policy variation in the SCIALs. We found evidence that a single factor described the majority of the variation in the SCIALs. When we controlled directly for this single factor along with the own-venue SCIAL (i.e., excluding the controls for SCIALs in other venues), we continued to find no compliance effects for any group of workers except bartenders (results not shown but available upon request). Second, we estimated the same specifications as in Columns 2 and 3 of Table IV for the other groups of workers (e.g., excluding all other SCIALs not applying directly to that group and summarizing the other SCIALs into a single summary index measure). When we controlled only for the own-venue SCIAL (as in Column 2 of Table IV), we continued to find no significant compliance effects of own-venue SCIALs for government workers or school employees. We did, however, find that private workplace SCIALs were estimated to significantly increase workplace smoking restrictions among private sector workers and that restaurant SCIALs were

\footnotetext{
${ }^{20}$ Specifically, individuals who report an official policy are asked about the workplace smoking policy pertaining to public or common areas "such as lobbies, rest rooms, and lunch rooms." Individuals are then asked about the workplace smoking policy pertaining to "work areas." The CPS TUS also contain questions about secondhand smoke (SHS) exposure. We do not report those results here because, until the 2006 wave, these questions were only asked of individuals who reported the presence of a workplace smoking restriction. As such, there may be composition bias to the sample with valid responses, which makes interpreting any relationship between SCIALs and SHS exposure difficult.
} 
estimated to significantly increase workplace smoking restrictions among the sample of eating and drinking place workers. When we controlled for the sum of strength-weighted SCIALs in the 11 other venues, however, the own-venue compliance relationship was not robust for either private sector workers or restaurant workers. This suggests that omitted variable bias contaminates the observed positive association between private workplace SCIALs and reports of official smoking restrictions among private sector workers and between restaurant SCIALs and reports of official smoking restrictions among eating and drinking place workers when no other SCIALs are included. Thus, we conclude that that there is no meaningful compliance effect of SCIALs covering private workplaces or restaurants (in addition to the consistently null findings for government workplace and school SCIALs).

\subsection{Venue-Specific SCIAL Effects on Smoking}

We now turn to the effects of venue-specific SCIALs on smoking participation and smoking intensity, respectively, for the relevant groups of workers. ${ }^{21}$ If there is a direct causal relationship between SCIALs and smoking behaviors, then we would expect that smoking should fall most in the same venue and for the same group for which the compliance effect is most clear. That is, we would expect bartenders to reduce smoking in response to SCIALs covering bars. More generally, we would expect smoking reductions among workers directly affected by venuespecific worksite smoking restrictions. We therefore look at smoking participation in Table $\mathrm{V}$ and smoking intensity conditional on smoking in Table VI. Both tables take the same format as

\footnotetext{
${ }^{21}$ Further robustness tests are described in the Data Appendix posted at the corresponding author's website. In results not shown but available upon request, we also estimated models of smoking for the full sample of individuals who gave valid responses to the question about official workplace smoking restrictions. In this sample, none of the 12 venue-specific SCIALs were significantly related to smoking participation. We did find a negative and statistically significant relationship between state excise taxes on cigarettes and the probability an individual reports being a current smoker. Specifically, we estimate that a one dollar increase in the state cigarette tax reduces smoking probability by 1.08 percentage points $(|t|=2.42)$. This basic result has also been found in earlier work using the CPS TUS (e.g., Tauras, 2004).
} 
Table III: each column represents a separate group of workers, and we show coefficient estimates for each venue-specific SCIAL. The samples in Table V for smoking are the same as those in Tables III: non self-employed individuals who work indoors and reported their workplace smoking policies. The samples in Table VI further condition on being a smoker.

The results provide some limited evidence that venue-specific SCIALs directly reduced smoking. Specifically, we find a significant negative relationship between SCIALs covering bars and smoking among bartenders in Column 5 of Table V. A one unit increase in the bar SCIAL variable is estimated to reduce smoking participation by 5.8 percentage points. This suggests that SCIALs covering bars reduced the fraction of bartenders who smoke by about 6.7 percentage points $\left(5.8^{*} 1.17\right)$, or by about 13 percent relative to the sample mean $(6.7 / 51)$. These findings for bartenders - whose worksites were directly affected by the relevant venue-specific SCIALs_ - are consistent with a direct role for SCIAL-induced worksite smoking policies to significantly reduce smoking. ${ }^{22}$

A broader evaluation of Tables $\mathrm{V}$ and VI provides little other evidence that venuespecific SCIALs affect smoking in a predictable way. When venue-specific SCIALs are estimated to have statistically significant relationships with smoking, those relationships are about as likely to indicate harmful effects of SCIALs as they are to indicate reductions in smoking related to SCIALs. Overall, the results do not provide strong evidence that SCIALs reduced smoking through the mechanism of direct exposure to stronger worksite restrictions.

\footnotetext{
${ }^{22}$ This reduction in smoking also may arise from other sources, making it inappropriate to calculate a direct elasticity of smoking with respect to smoking restrictions. We cannot, for example, definitively rule out that SCIALs covering bars reduce bar employment (as suggested by Adams and Cotti, 2007) and do so disproportionately among smokers.
} 


\section{CONCLUSION}

Previous research examining the effects of state clean indoor air laws has generally examined the effects of laws in an aggregated or "strength-weighted index" form despite the fact that there is a great deal of variation with respect to the specific venues covered by SCIALs. Moreover, most existing research focuses only on smoking outcomes, largely ignoring worksite compliance—a key mechanism through which the laws would be expected (and usually are presumed) to affect smoking. We used detailed labor market information from the CPS TUS to identify groups of workers who should have been directly affected by venue-specific restrictions because they work at locations covered by those laws and to directly test for compliance effects.

Our results uncover very limited evidence that venue-specific SCIALs adopted by US states over 1992-2007 actually changed the worksite smoking policies of workers who should have been directly affected because they worked in locations covered by the SCIALs. SCIALs covering private workplaces, government workplaces, schools, and restaurants are not estimated to have significantly increased reports of worksite smoking restrictions by private sector workers, government sector workers, school employees, and eating/drinking place workers, respectively. We similarly found no evidence that venue-specific SCIALs reduced smoking for these groups of workers, which is not surprising given the lack of evidence that these SCIALs changed actual worksite smoking policies.

The one exception to these results is the case of bartenders in eating and drinking places. We consistently find that SCIALs covering bars are estimated to significantly increase reports of official workplace smoking restrictions and reduce smoking among bartenders. These effects of SCIALs covering bars are unique to bartenders and are robust to a variety of alternative 
specifications, increasing our confidence that these effects are real. Our finding that bars differ from other workplaces is perhaps not surprising. Bars are one of the last indoor workplaces to be covered by clean indoor air laws in most states. In 1992, only 2 states had laws restricting smoking in bars, compared with 19 states with laws restricting smoking in private workplaces. Bar owners and managers are likely to have been much more reluctant than other workplaces to voluntarily restrict smoking because of concerns about losing customers and profits, giving more scope for SCIALS to affect actual practices. Indeed, at the start of our sample period in 199293 , only $38 \%$ of bartenders reported that their workplace had any official policy restricting smoking; the comparable figure for private sector workers was $80 \%$.

Overall, the patterns of null findings for all groups of workers except bartenders suggest that any estimated smoking reductions in previous research associated with SCIALs were unlikely to have been brought about by workers' direct exposure to stronger worksite smoking restrictions. Other mechanisms (e.g., unobserved heterogeneity, peer effects, customer effects, or changes in social norms) are more likely to be responsible for the smoking reductions associated with adoption of state clean indoor air laws reported in previous research. Regardless of the exact mechanism, any interpretation that attributes observed smoking reductions to SCIALs requires that the laws actually changed smoking restrictions in that state. Among the venues for which we can identify groups of workers who should have been directly affected, our results suggest this was the case only for SCIALs covering bars. 


\section{Data Appendix}

Our analysis uses data from all available rounds of the CPS Tobacco Use Supplement (CPS TUS) that report data on whether workplaces have a policy banning smoking. This includes data from 6 cycles of the CPS TUS, 1992-1993 (September 1992, January 1993, and May 1993); 1995-1996 (September 1995, January 1996, and May 1996); 1998-1999 (September 1998, January 1999, and May 1999): 2001-2002 (June 2001, November 2001, and February 2002); 2003 (February 2003, June 2003, and November 2003); and 2006-2007 (May 2006, August 2006, and January 2007). While there was an abbreviated version of the CPS TUS done in January 2000 and May 2000, no questions were asked about workplaces restricting smoking.

Our specifications restrict the sample to self-respondents (because the questions about workplace bans and number of cigarettes were only asked of self-respondents, while the smoking questions were asked of proxy respondents) and use the supplement self-response weights. We also therefore use the self-response weights to obtain population representative results. This yields a maximum of 1,133,546 observations for adults 18 and older with a valid non-zero selfresponse weight. All of our samples exclude individuals who have an invalid response for smoking status (unknown or indeterminate), which reduces our sample by 3,312 observations. We drop a further 417,536 observations for individuals not in the labor force or unemployed and a further 85,911 for individuals who are self-employed or not working for pay (neither group was asked about workplace smoking policies). A further 7,682 answered refused/don't know or had no response to the questions about working indoors. The workplace smoking policy questions were only asked of those who work indoors (and not at home); we lose another 111,665 observations because the individuals work outdoors/in a vehicle/at a home/or at varied locations. Finally, we lose 5,643 observations among people who answered refused/don't know or had no 
answer recorded for the workplace smoking bans, and we lose 1 observation who is neither currently working nor has a job and is on layoff but has a valid workplace policy ban variable, yielding a final sample of 501,796 workers (404,989 private sector workers $+96,807$ government workers) with responses to the workplace smoking policies.

Groups of workers were created as follows:

- Private sector: class of worker equals 4 or 5 .

- Government (state/local/federal): class of worker equals 1, 2, or 3 .

- School employees (elementary or secondary school): detailed industry classification 842 "elementary and secondary schools" for the 2002 and earlier surveys, and 7860 "elementary and secondary schools" for the 2003 and later surveys.

- Eating or drinking place employees: detailed industry code 641 ("eating and drinking places") for the 2002 and earlier surveys, and detailed industry classifications 8680 ("restaurants and other food services") and 8690 (“drinking places, alcoholic beverages") for the 2003 and later surveys.

- Bartenders in eating or drinking places: eating and drinking place workers combined with detailed occupation code 434 ("bartenders") for the 2002 and earlier surveys, and 4040 ("bartenders") for the 2003 and later surveys.

For some robustness specifications (the bulk of which are not reported in the paper), we also looked separately at a work area ban variable and a public area ban variable. The work area ban variable is set to be 1 for those who report their workplace had a policy completely banning smoking in work areas; 0 for those who report their workplace had a policy allowing smoking in some or all work areas; and 0 for those not asked about the smoking policy for work areas (those 
whose workplace had no official policy restricting smoking). The public area ban variable is set to be 1 for those who report their workplace had a policy completely banning smoking in public or common areas such as lobbies, restrooms, and lunch rooms; 0 for those who report their workplace had a policy allowing smoking in some or all work areas; and 0 for those not asked about the smoking policy for work areas (those who have no official policy restricting smoking). The smoking specifications are estimated on the set of workers who answered the any official policy variable. We also restricted the sample to be at least 18 years old (in later years of the CPS TUS only those 18 and older are asked about smoking behavior).

Controls in all specifications included state, year, and month of survey fixed effects. Additional individual controls are age and age squared; dummies for male; marital status (never married, or widowed/divorced/separated); race (black/Asian/other non white); ethnicity (Hispanic); educational attainment (high school dropout, exactly a high school degree or GED, some college but not a four year degree, a 4 year degree but no graduate work); dummies for family income being in 1 of 15 categories (this includes a missing category; in the later years, several high income categories are collapsed to maintain consistency with the earlier period); and a dummy for not living in an MSA. In addition to the ban variables; other controls varying at the state and year level include the following: the real state excise tax for cigarettes for the survey month (from Orzechoswki and Walker's 2004 edition of The Tax Burden on Tobacco: Historical Compilation, and updated for the later period with Cigarette Tax Increases by State per Year 2000-2009 from the Campaign for Tobacco Free Kids, deflated by the personal consumption expenditure deflator); the unemployment rate (statewide annual numbers from the Bureau of Labor Statistics); the employment growth rate (constructed from statewide total employment numbers from the Bureau of Economic Statistics; and the percent of the state population that is in 
poverty by state (from the Census Bureau). Standard errors are clustered at the state level and self-response weights are used throughout.

\section{Further Robustness}

We estimate a battery of additional specifications to test the robustness of our venuespecific models in equation (1). For example, we also estimate models where-for specific venues of interest — we control for whether the venue has a 'strong' 100\% smoke-free ban (as opposed to weaker restrictions such as requiring separate ventilation systems or designated smoking areas). One might expect these stronger bans to have relatively larger effects on workplace restrictions and own smoking outcomes. It is also possible, however, that weak bans will have a larger effect on workplace restrictions, as the outcome measure in the CPS covers any policy restricting smoking. We consider models that include linear state trends. To do so we construct a variable Trend which equals 1 in 1992, 2 in 1993, and so forth, and we interact the trend variable with each of the state dummy variables. In models that include these smooth state trends, the effects of SCIALs are identified from sharp changes in outcomes relative to smooth underlying trends for each state coincident with adoption of the venue-specific policy. We estimated specifications controlling for preemption laws (as coded by ImpacTeen), which restrict local areas from enforcing laws that are stricter than the statewide law.

ImpacTeen codes policies in a few venues as $3^{*}$ (generally not as strong as 3 but still much stronger than 2). It usually means a ban in areas open to the public but allows for separate ventilated areas. In our main results, we code polices denoted as $3 *$ as $3 \mathrm{~s}$. We also tested the robustness of our findings to coding policies denoted as $3^{*}$ by ImpacTeen to 2 instead of 3 , all results reported in the tables are robust to this. (It affects from 1 state for public transit to 6 states

for malls.) Lastly, we explored one other robustness issue with the ImpacTeen coding. Their 
own documentation indicates that public transit should range from $0-3$, but there are two states with public transit coded as a 5 or as a $3^{*}$, deviating from the ImpacTeen codebook description. Ohio passed a balled measure in 2006 that banned smoking almost everywhere. In the ImpacTeen public data base, they coded public transit as a 5 for that year. Oregon codes public transit as a $3 *$ for some years. We estimate our main models setting this public transit variable to 3 for Ohio and Oregon for the relevant years, and the results are unchanged.

To allay any concerns about policy multicollinearity, we estimated a series of models. We estimated models controlling for the own ban and the statewide measure of smoking sentiment described in DeCicca, Kenkel, Mathios, Sin, and Kim's 2008 article in Economic Inquiry for the period through the 2003 data. We estimated principal components for the 12 smoking bans, and controlled for both the own specific venue ban and the first principal component (the only one with an eigenvalue above 1) for each of our venues. We estimated models controlling only for the own venue ban or controlling for it and the sum of the other venue bans.

We also tested the robustness of our results to not turning on the bar bans until they actually were implemented (i.e., only for the months in a year after they went into effect instead of for the full year in which they were implemented regardless of the month of actual implementation, as in the ImpacTeen data). These results were nearly identical to the results reported in the text. For example, for the specification reported in column 1 of Table IV, the implementation date bar ban variable point estimate is .107 (SE of .044) compared to the estimate of .113 (SE of .041) reported in column 1 of Table IV. Similarly, the column 2 specification, the implementation date bar ban variable point estimate is .134 (SE of .021) compared to the estimate reported in column 2 of Table IV of .132 (SE of .019). 
We use information on MSA of residence for individuals in the CPS TUS data matched to coverage of local smoking ordinances from the American for Nonsmokers' Rights Foundation (ANRF). The ANRF data track local ordinances covering private workplaces, restaurants, and bars. $^{23}$ The CPS implemented the new 2000 Geographic concepts in May 2004. This means that the ANRF robustness tests are only conducted through the 2003 data.

We performed two last robustness checks. First, we verified that the results are robust to leaving out the dummy for not living in an MSA, to allay concerns that the changed geographic concepts may introduce bias. Second, we estimated our main models leaving out the income dummies.

Our main findings are robust to all of these alternative specifications.

\footnotetext{
${ }^{23}$ The ANRF policy tracking system has some disadvantages, including the fact that it is passive as opposed to active. We obtained a data extract from ANRF that included local coverage of smoking ordinances for private workplaces, restaurants, and bars. We did not obtain information on local coverage of ordinances covering government workplaces, although other research has used this information (see, for example, Shipan and Volden's 2006 article in American Journal of Political Science).
} 


\section{References}

Adams S, Cotti C. 2007. The effect of smoking bans on bars and restaurants: An analysis of changes in employment. B. E. Journal of Economic Analysis \& Policy, 7(1) Contributions, Article 12.

Adda J, Cornaglia F. 2009. The effect of taxes and bans on passive smoking. American Economic Journal: Applied Economics, forthcoming.

Bertrand M, Duflo E, Mullainathan S. 2004. How much should we trust difference in differences estimates? Quarterly Journal of Economics, 119: 249-275.

Campaign for Tobacco Free Kids. 2009. Cigarette tax increases by state per year 2000-2009. http://www.tobaccofreekids.org/research/factsheets/pdf/0275.pdf [5 July 2009].

Carpenter C. 2009. The effects of local workplace smoking laws on exposure to smoke at work. Journal of Human Resources, forthcoming.

Chaloupka F. 1992. Clean indoor air laws, addiction, and cigarette smoking. Applied Economics 24: 193-205.

Cragg J. 1971. Some statistical methods for limited dependent variables with application to the demand for durable goods. Econometrica, 39: 829-844.

Cutler D, Glaeser E. 2007. Social interactions and smoking. NBER Working Paper No. 13477.

DeCicca P, Kenkel D, Mathios A, Shin Y, Lim J. 2008. Youth smoking, cigarette prices, and anti-smoking sentiment, Health Economics, 17: 733-749.

Duan N, Manning W, Morris C, Newhouse J. 1983. A comparison of alternative models for the demand for medical care. Journal of Business and Economic Statistics, 1: 115-126.

Emont S, Choi W, Novotny T, Giovino G. 1993. Clean indoor air legislation, taxation, and smoking behaviour in the United States: An ecological analysis. Tobacco Control, 2: 13-17.

Evans W, Farrelly M, Montgomery E. 2002. Do workplace bans reduce smoking? American Economic Review 89: 728-747.

ImpacTeen. 2009. Tobacco control policy and prevalence data: 1991-2008. Codebook and definitions. http://www.impacteen.org/statetobaccodata/Codebook.pdf [5 July 2009].

Lovenheim M. 2008. How far to the border? The extent and impact of cross-border casual cigarette smuggling. National Tax Journal, 61 7-33. 
Manning W, Morris C, Newhouse J, et al. 1981. A two-part model of the demand for medical care: Preliminary results from the Health Insurance Study. In: van der Gaag J, Perlman M, eds. Health, Economics, and Health Economics. North Holland, Amsterdam, 102-123.

Mullahy J. 1998. Much ado about two: Reconsidering retransformation and two-part model in health econometrics. Journal of Health Economics, 17: 247-281.

Orzechowski W, Walker RC. 2004. The Tax Burden on Tobacco: Historical Compilation, Volume 39. Arlington VA.

Shopland D, Anderson C, Burns D, Gerlach K. 2004. Disparities in smoke-free workplace policies among food service workers. Journal of Occupational and Environmental Medicine 46: 347-356.

Tauras J. 2006. Smoke-free air laws, cigarette prices, and adult cigarette demand. Economic Inquiry 44: 333-342.

Tauras J. 2004. Public policy and some-day smoking among adults. Journal of Applied Economics 7: 137-162.

Wasserman J, Manning W, Newhouse J, Winkler J. 1991. The effects of excise taxes and regulations on cigarette smoking, Journal of Health Economics 10: 43-64.

Yurkeli A, Zhang P. 2000. The impact of clean indoor-air laws and cigarette smuggling on demand for cigarettes: An empirical model. Health Economics 9: 159-170. 
Table I. Average strength-weighted indices of venue-specific state clean indoor air laws

\begin{tabular}{|c|c|c|c|c|c|c|c|c|c|c|c|c|}
\hline & Private & Government & $\begin{array}{c}\text { Public } \\
\text { schools }\end{array}$ & $\begin{array}{l}\text { Private } \\
\text { schools }\end{array}$ & Restaurants & Bars & $\begin{array}{c}\text { Child } \\
\text { care } \\
\text { centers }\end{array}$ & $\begin{array}{c}\text { Health } \\
\text { care } \\
\text { facilities }\end{array}$ & $\begin{array}{c}\text { Recreational } \\
\text { facilities }\end{array}$ & $\begin{array}{l}\text { Cultural } \\
\text { facilities }\end{array}$ & $\begin{array}{l}\text { Public } \\
\text { transit }\end{array}$ & $\begin{array}{c}\text { Shopping } \\
\text { malls }\end{array}$ \\
\hline 1992 & .39 & .62 & 1.08 & .62 & .49 & .03 & .74 & .93 & .74 & 1.37 & 1.53 & .06 \\
\hline 1993 & .39 & .67 & 1.29 & .62 & .48 & .03 & .87 & .95 & .76 & 1.41 & 1.54 & .06 \\
\hline 1995 & .67 & .95 & 1.92 & 1.15 & .86 & .03 & 2.05 & 1.26 & 1.37 & 2.00 & 1.45 & .50 \\
\hline 1996 & .66 & .94 & 1.93 & 1.15 & .86 & .03 & 2.05 & 1.25 & 1.35 & 2.00 & 1.45 & .48 \\
\hline 1998 & .66 & .99 & 1.97 & 1.14 & .86 & .36 & 2.18 & 1.24 & 1.36 & 2.00 & 1.55 & .49 \\
\hline 1999 & .66 & 1.01 & 2.06 & 1.20 & .86 & .37 & 2.17 & 1.25 & 1.36 & 2.00 & 1.55 & .49 \\
\hline 2001 & .67 & 1.03 & 2.27 & 1.22 & .88 & .38 & 2.22 & 1.26 & 1.38 & 2.01 & 1.55 & .51 \\
\hline 2002 & .71 & 1.05 & 2.30 & 1.25 & .88 & .39 & 2.24 & 1.29 & 1.41 & 2.04 & 1.59 & .56 \\
\hline 2003 & .99 & 1.32 & 2.43 & 1.41 & 1.15 & .58 & 2.38 & 1.57 & 1.62 & 2.26 & 1.64 & .99 \\
\hline 2006 & 1.51 & 1.75 & 2.77 & 2.01 & 1.64 & 1.11 & 2.83 & 2.01 & 2.46 & 2.94 & 1.94 & 1.59 \\
\hline 2007 & 1.67 & 1.82 & 2.80 & 2.05 & 1.77 & 1.19 & 2.95 & 2.10 & 2.65 & 3.05 & 2.00 & 1.69 \\
\hline
\end{tabular}

Notes: Authors' tabulations of means of the venue-specific restrictions from the ImpacTeen database (www.impacteen.org) for the 51 states and D.C. for each year, weighted using the population age 18 and older in the CPS TUS with valid responses to the question about workplace smoking restrictions (indoor workers who answered the survey themselves). The values for restrictions in each venue range from 0 to 3 except for public schools, private schools, child care centers, recreational facilities, cultural facilities, and public transit which range from 0 to 5. 
Table II. Descriptive statistics

(1)

\begin{tabular}{|c|c|c|c|c|c|}
\hline & \multirow[b]{2}{*}{$\begin{array}{c}\text { Private sector } \\
\text { workers }\end{array}$} & \multirow[b]{2}{*}{$\begin{array}{c}\text { Government sector } \\
\text { workers } \\
\end{array}$} & \multirow[b]{2}{*}{ School workers } & \multicolumn{2}{|c|}{ Eating/drinking places } \\
\hline & & & & All workers & Bartenders \\
\hline Workplace restricts smoking & $\begin{array}{c}.851 \\
(.356)\end{array}$ & $\begin{array}{c}.955 \\
(.207)\end{array}$ & $\begin{array}{c}.965 \\
(.185)\end{array}$ & $\begin{array}{c}.766 \\
(.423)\end{array}$ & $\begin{array}{c}.426 \\
(.495)\end{array}$ \\
\hline Current smoker & $\begin{array}{l}.228 \\
(.419)\end{array}$ & $\begin{array}{l}.146 \\
(.353)\end{array}$ & $\begin{array}{l}.104 \\
(.305)\end{array}$ & $\begin{array}{c}.341 \\
(.474)\end{array}$ & $\begin{array}{c}.507 \\
(.500)\end{array}$ \\
\hline $\begin{array}{l}\text { Number of cigarettes last } 30 \text { days } \\
\text { among current smokers }\end{array}$ & $\begin{array}{c}445 \\
(307)\end{array}$ & $\begin{array}{c}424 \\
(307)\end{array}$ & $\begin{array}{c}370 \\
(287)\end{array}$ & $\begin{array}{l}435 \\
(299)\end{array}$ & $\begin{array}{c}501 \\
(339)\end{array}$ \\
\hline
\end{tabular}

Notes: Shown are weighted sample means (standard deviations) among indoor workers from the 1992-2007 Tobacco Use Supplements to the Current Population Survey with valid responses to the question about workplace smoking restrictions. Private sector workers and government workers are defined by respective class of worker codes in the CPS. School employees and eating and drinking place workers are defined by industry codes in the CPS. Bartenders are identified by occupation codes in the CPS; only bartenders in eating and drinking places are included here. 


\section{Table III. Estimated effects of venue-specific SCIALs on whether workplace restricts smoking at all, various groups of workers}

\begin{tabular}{|c|c|c|c|c|c|}
\hline & \multirow[t]{2}{*}{ (1) } & \multirow[t]{2}{*}{ (2) } & \multirow[t]{2}{*}{ (3) } & \multirow{2}{*}{\multicolumn{2}{|c|}{$\begin{array}{l}(4) \\
\text { Eating/drinking places }\end{array}$}} \\
\hline & & & & & \\
\hline & $\begin{array}{c}\text { Private sector } \\
\text { workers }\end{array}$ & $\begin{array}{l}\text { Government } \\
\text { workers }\end{array}$ & $\begin{array}{c}\text { School } \\
\text { employees }\end{array}$ & All workers & Bartenders \\
\hline $\begin{array}{l}\text { Private } \\
\text { workplaces }\end{array}$ & $\begin{array}{c}.003 \\
(.007)\end{array}$ & $\begin{array}{l}-.004 \\
(.004)\end{array}$ & $\begin{array}{l}-.010 \\
(.007)\end{array}$ & $\begin{array}{l}-.004 \\
(.012)\end{array}$ & $\begin{array}{c}.001 \\
(.097)\end{array}$ \\
\hline $\begin{array}{l}\text { Government } \\
\text { workplaces }\end{array}$ & $\begin{array}{c}.006 \\
(.004)\end{array}$ & $\begin{array}{l}.003 \\
(.002)\end{array}$ & $\begin{array}{c}.003 \\
(.006)\end{array}$ & $\begin{array}{c}.011 \\
(.009)\end{array}$ & $\begin{array}{l}-.028 \\
(.054)\end{array}$ \\
\hline Public schools & $\begin{array}{l}.002 \\
(.002)\end{array}$ & $\begin{array}{l}.003 * \\
(.002)\end{array}$ & $\begin{array}{l}.002 \\
(.002)\end{array}$ & $\begin{array}{l}-.001 \\
(.005)\end{array}$ & $\begin{array}{l}-.027 \\
(.028)\end{array}$ \\
\hline Private schools & $\begin{array}{l}-.002 \\
(.003)\end{array}$ & $\begin{array}{l}-.0004 \\
(.0018)\end{array}$ & $\begin{array}{l}.003 \\
(.002)\end{array}$ & $\begin{array}{l}.007 \\
(.006)\end{array}$ & $\begin{array}{l}.038 \\
(.034)\end{array}$ \\
\hline Restaurants & $\begin{array}{l}-.008 \\
(.004)\end{array}$ & $\begin{array}{l}-.002 \\
(.004)\end{array}$ & $\begin{array}{l}.001 \\
(.004)\end{array}$ & $\begin{array}{l}-.023 \\
(.014)\end{array}$ & $\begin{array}{l}-.039 \\
(.077)\end{array}$ \\
\hline Bars & $\begin{array}{l}-.003 \\
(.002)\end{array}$ & $\begin{array}{l}-.0005 \\
(.0025)\end{array}$ & $\begin{array}{c}-.005^{* *} \\
(.002)\end{array}$ & $\begin{array}{l}.009 \\
(.006)\end{array}$ & $\begin{array}{l}.113 * * \\
(.041)\end{array}$ \\
\hline $\begin{array}{l}\text { Child care } \\
\text { centers }\end{array}$ & $\begin{array}{l}.001 \\
(.002)\end{array}$ & $\begin{array}{l}-.002 \\
(.002)\end{array}$ & $\begin{array}{l}-.002 \\
(.002)\end{array}$ & $\begin{array}{l}-.003 \\
(.005)\end{array}$ & $\begin{array}{l}.027 \\
(.019)\end{array}$ \\
\hline $\begin{array}{l}\text { Health care } \\
\text { facilities }\end{array}$ & $\begin{array}{l}.003 \\
(.006)\end{array}$ & $\begin{array}{l}.003 \\
(.005)\end{array}$ & $\begin{array}{l}.005 \\
(.005)\end{array}$ & $\begin{array}{l}-.009 \\
(.016)\end{array}$ & $\begin{array}{l}-.005 \\
(.085)\end{array}$ \\
\hline $\begin{array}{l}\text { Recreational } \\
\text { facilities }\end{array}$ & $\begin{array}{l}.002 \\
(.004)\end{array}$ & $\begin{array}{l}-.002 \\
(.003)\end{array}$ & $\begin{array}{l}.002 \\
(.003)\end{array}$ & $\begin{array}{l}.002 \\
(.010)\end{array}$ & $\begin{array}{l}-.013 \\
(.038)\end{array}$ \\
\hline $\begin{array}{l}\text { Cultural } \\
\text { facilities }\end{array}$ & $\begin{array}{l}-.002 \\
(.005)\end{array}$ & $\begin{array}{c}.001 \\
(.003)\end{array}$ & $\begin{array}{l}-.002 \\
(.003)\end{array}$ & $\begin{array}{l}.016 \\
(.010)\end{array}$ & $\begin{array}{c}.003 \\
(.049)\end{array}$ \\
\hline Public transit & $\begin{array}{l}.001 \\
(.002)\end{array}$ & $\begin{array}{l}.001 \\
(.003)\end{array}$ & $\begin{array}{l}-.002 \\
(.002)\end{array}$ & $\begin{array}{l}-.009 \\
(.006)\end{array}$ & $\begin{array}{l}-.030 \\
(.036)\end{array}$ \\
\hline Shopping malls & $\begin{array}{l}.005 \\
(.005)\end{array}$ & $\begin{array}{c}.003 \\
(.004)\end{array}$ & $\begin{array}{l}.006 \\
(.004)\end{array}$ & $\begin{array}{c}.017 \\
(.014)\end{array}$ & $\begin{array}{l}.059 \\
(.098)\end{array}$ \\
\hline $\mathrm{N}$ & 404989 & 96807 & 43207 & 25085 & 1380 \\
\hline
\end{tabular}

Notes: * Significant at 5\%; ** significant at 1\%. Shown are estimated coefficients from OLS regressions (each column is a separate model). The dependent variable is an indicator variable equal to one if the individual reports that her workplace has an official policy on workplace smoking. Robust standard errors clustered at the state level are in parentheses. Observations are weighted with the CPS TUS self-response supplement weight. All samples include only indoor workers. Private sector workers and government workers are defined by respective class of worker codes in the CPS. School employees and eating and drinking place workers are defined by industry codes in the CPS. Bartenders are identified by occupation codes in the CPS; only bartenders in eating and drinking places are included here. Additional controls not reported (but available upon request) include: survey month, year, and state fixed effects, the real excise tax on a pack of cigarettes, and the individual and state demographic characteristics described in the text. 
Table IV. Robustness of estimated effects of bar SCIALs on workplace smoking restrictions, as reported by bartenders

\begin{tabular}{|c|c|c|c|c|c|c|}
\hline & $\begin{array}{c}(1) \\
\text { Baseline } \\
\text { specification, } \\
\text { Column } 5 \text { of Table } \\
\text { III }\end{array}$ & $\begin{array}{c}\text { (2) } \\
\text { (1), but drop all } \\
\text { SCIALs except } \\
\text { SCIALs covering } \\
\text { bars }\end{array}$ & $\begin{array}{l}\text { (3) } \\
\text { (1), but instead of } \\
\text { controlling for all } \\
\text { other SCIALs } \\
\text { separately control } \\
\text { for the sum of the } \\
\text { other SCIALs }\end{array}$ & $\begin{array}{c}\text { (4) } \\
(1)+\text { state-specific } \\
\text { linear time trends }\end{array}$ & $\begin{array}{l}\text { (5) } \\
\text { (1), outcome is ban } \\
\text { on smoking in work } \\
\text { areas at workplace }\end{array}$ & $\begin{array}{c}(6) \\
(1), \text { outcome is ban } \\
\text { on smoking in } \\
\text { public areas at } \\
\text { workplace }\end{array}$ \\
\hline Outcome is: & $\begin{array}{l}\text { Any smoking } \\
\text { restriction }\end{array}$ & $\begin{array}{l}\text { Any smoking } \\
\text { restriction }\end{array}$ & $\begin{array}{l}\text { Any smoking } \\
\text { restriction }\end{array}$ & $\begin{array}{l}\text { Any smoking } \\
\text { restriction }\end{array}$ & $\begin{array}{l}\text { Work area smoking } \\
\text { ban at workplace }\end{array}$ & $\begin{array}{c}\text { Public area smoking } \\
\text { ban at workplace }\end{array}$ \\
\hline Bar SCIAL & $\begin{array}{l}.113 * * \\
(.041)\end{array}$ & $\begin{array}{l}.132 * * \\
(.019)\end{array}$ & $\begin{array}{l}.118 * * \\
(.026)\end{array}$ & $\begin{array}{l}.165^{* *} \\
(.060)\end{array}$ & $\begin{array}{l}.170 * * \\
(.031)\end{array}$ & $\begin{array}{l}.141 * * \\
(.028)\end{array}$ \\
\hline $\begin{array}{l}\text { Sum of SCIALs in } \\
\text { other venues }\end{array}$ & --- & --- & $\begin{array}{l}.003 \\
(.003)\end{array}$ & --- & --- & --- \\
\hline $\mathrm{N}$ & 1380 & 1380 & 1380 & 1380 & 1380 & 1380 \\
\hline \multicolumn{7}{|c|}{$\begin{array}{l}\text { Notes: } * \text { Significant at } 5 \% ; * \text { significant at } 1 \% \text {. Shown are estimated coefficients from OLS regressions (each column is a separate model). The dependent } \\
\text { variable in Columns } 1-4 \text { is an indicator variable equal to one if the individual reports that her workplace has an official policy on workplace smoking; in Column } \\
5 \text {, an indicator for a ban on smoking in work areas; in Column } 6 \text {, an indicator for a ban on smoking in public areas at the workplace. Robust standard errors } \\
\text { clustered at the state level are in parentheses. Observations are weighted with the CPS TUS self-response supplement weight. All samples include only indoor } \\
\text { workers. Bartenders are identified by occupation codes in the CPS; only bartenders in eating and drinking places are included here. Additional controls not } \\
\text { reported (but available upon request) include: survey month, year, and state fixed effects, the real excise tax on a pack of cigarettes, and the individual and state } \\
\text { demographic characteristics described in the text. }\end{array}$} \\
\hline
\end{tabular}




\section{Table V. Estimated effects of venue-specific SCIALs on smoking participation, various groups of workers}

\begin{tabular}{|c|c|c|c|c|c|}
\hline & \multirow[t]{2}{*}{ (1) } & \multirow[t]{2}{*}{ (2) } & \multirow[t]{2}{*}{ (3) } & \multirow{2}{*}{\multicolumn{2}{|c|}{$\begin{array}{l}\text { (4) } \\
\text { Eating/drinking places }\end{array}$}} \\
\hline & & & & & \\
\hline & $\begin{array}{c}\text { Private sector } \\
\text { workers }\end{array}$ & $\begin{array}{c}\text { Government } \\
\text { workers }\end{array}$ & $\begin{array}{c}\text { School } \\
\text { employees }\end{array}$ & All workers & Bartenders \\
\hline $\begin{array}{l}\text { Private } \\
\text { workplaces }\end{array}$ & $\begin{array}{l}.001 \\
(.003)\end{array}$ & $\begin{array}{l}-.004 \\
(.006)\end{array}$ & $\begin{array}{l}-.008 \\
(.008)\end{array}$ & $\begin{array}{c}.002 \\
(.011)\end{array}$ & $\begin{array}{l}.055 \\
(.068)\end{array}$ \\
\hline $\begin{array}{l}\text { Government } \\
\text { workplaces }\end{array}$ & $\begin{array}{l}-.005^{*} \\
(.002)\end{array}$ & $\begin{array}{l}.011 \\
(.009)\end{array}$ & $\begin{array}{l}.013 \\
(.009)\end{array}$ & $\begin{array}{l}.004 \\
(.012)\end{array}$ & $\begin{array}{l}.014 \\
(.050)\end{array}$ \\
\hline Public schools & $\begin{array}{l}.001 \\
(.001)\end{array}$ & $\begin{array}{l}.001 \\
(.002)\end{array}$ & $\begin{array}{l}-.001 \\
(.003)\end{array}$ & $\begin{array}{l}.006 \\
(.005)\end{array}$ & $\begin{array}{l}.037 \\
(.022)\end{array}$ \\
\hline Private schools & $\begin{array}{l}-.002 \\
(.001)\end{array}$ & $\begin{array}{l}-.001 \\
(.002)\end{array}$ & $\begin{array}{l}-.004 \\
(.004)\end{array}$ & $\begin{array}{l}-.004 \\
(.008)\end{array}$ & $\begin{array}{c}-.072 * * \\
(.020)\end{array}$ \\
\hline Restaurants & $\begin{array}{l}.002 \\
(.003)\end{array}$ & $\begin{array}{l}.002 \\
(.005)\end{array}$ & $\begin{array}{l}.005 \\
(.007)\end{array}$ & $\begin{array}{l}.013 \\
(.014)\end{array}$ & $\begin{array}{l}.111 \\
(.060)\end{array}$ \\
\hline Bars & $\begin{array}{l}.0004 \\
(.0013)\end{array}$ & $\begin{array}{l}.001 \\
(.002)\end{array}$ & $\begin{array}{l}.003 \\
(.003)\end{array}$ & $\begin{array}{l}-.014 \\
(.008)\end{array}$ & $\begin{array}{c}-.058^{* *} \\
(.021)\end{array}$ \\
\hline $\begin{array}{l}\text { Child care } \\
\text { centers }\end{array}$ & $\begin{array}{l}.001 \\
(.002)\end{array}$ & $\begin{array}{l}.002 \\
(.002)\end{array}$ & $\begin{array}{l}.005 \\
(.003)\end{array}$ & $\begin{array}{l}-.010 \\
(.005)\end{array}$ & $\begin{array}{l}.013 \\
(.030)\end{array}$ \\
\hline $\begin{array}{l}\text { Health care } \\
\text { facilities }\end{array}$ & $\begin{array}{l}.004 \\
(.004)\end{array}$ & $\begin{array}{l}-.011 \\
(.007)\end{array}$ & $\begin{array}{l}-.005 \\
(.007)\end{array}$ & $\begin{array}{l}.033 \\
(.024)\end{array}$ & $\begin{array}{l}-.035 \\
(.068)\end{array}$ \\
\hline $\begin{array}{l}\text { Recreational } \\
\text { facilities }\end{array}$ & $\begin{array}{l}.002 \\
(.003)\end{array}$ & $\begin{array}{l}-.002 \\
(.004)\end{array}$ & $\begin{array}{l}.002 \\
(.005)\end{array}$ & $\begin{array}{l}.023 * \\
(.010)\end{array}$ & $\begin{array}{l}-.082^{*} \\
(.035)\end{array}$ \\
\hline $\begin{array}{l}\text { Cultural } \\
\text { facilities }\end{array}$ & $\begin{array}{l}-.006 \\
(.003)\end{array}$ & $\begin{array}{c}.002 \\
(.005)\end{array}$ & $\begin{array}{l}-.006 \\
(.005)\end{array}$ & $\begin{array}{l}-.028^{*} \\
(.013)\end{array}$ & $\begin{array}{l}.060 \\
(.038)\end{array}$ \\
\hline Public transit & $\begin{array}{l}.002 \\
(.002)\end{array}$ & $\begin{array}{l}-.003 \\
(.003)\end{array}$ & $\begin{array}{l}-.005 \\
(.004)\end{array}$ & $\begin{array}{l}.002 \\
(.004)\end{array}$ & $\begin{array}{l}.045 \\
(.051)\end{array}$ \\
\hline Shopping malls & $\begin{array}{l}-.00005 \\
(.00248)\end{array}$ & $\begin{array}{l}.002 \\
(.007)\end{array}$ & $\begin{array}{l}.002 \\
(.006)\end{array}$ & $\begin{array}{l}-.023 \\
(.016)\end{array}$ & $\begin{array}{l}-.046 \\
(.057)\end{array}$ \\
\hline $\mathrm{N}$ & 404989 & 96807 & 43207 & 25085 & 1380 \\
\hline
\end{tabular}

Notes: * Significant at 5\%; ** significant at 1\%. Shown are estimated coefficients from OLS regressions (each column is a separate model). The dependent variable is an indicator variable equal to one if the individual is a current smoker (i.e. she reports she smokes every day or some days). Robust standard errors clustered at the state level are in parentheses. Observations are weighted with the CPS TUS self-response supplement weight. All samples include only indoor workers. Private sector workers and government workers are defined by respective class of worker codes in the CPS. School employees and eating and drinking place workers are defined by industry codes in the CPS. Bartenders are identified by occupation codes in the CPS; only bartenders in eating and drinking places are included here. Additional controls not reported (but available upon request) include: survey month, year, and state fixed effects, the real excise tax on a pack of cigarettes, and the individual and state demographic characteristics described in the text. 
Table VI. Estimated effects of venue-specific SCIALs on smoking intensity, various groups of workers

\begin{tabular}{|c|c|c|c|c|c|}
\hline & \multirow[t]{2}{*}{ (1) } & \multirow[t]{2}{*}{ (2) } & \multirow[t]{2}{*}{ (3) } & \multirow{2}{*}{\multicolumn{2}{|c|}{$\begin{array}{l}\text { (4) } \\
\text { Eating/drinking places }\end{array}$}} \\
\hline & & & & & \\
\hline & $\begin{array}{c}\text { Private sector } \\
\text { workers }\end{array}$ & $\begin{array}{c}\text { Government } \\
\text { workers }\end{array}$ & $\begin{array}{c}\text { School } \\
\text { employees }\end{array}$ & All workers & Bartenders \\
\hline $\begin{array}{l}\text { Private } \\
\text { workplaces }\end{array}$ & $\begin{array}{l}-.027 \\
(.031)\end{array}$ & $\begin{array}{l}.016 \\
(.044)\end{array}$ & $\begin{array}{l}.046 \\
(.102)\end{array}$ & $\begin{array}{l}-.057 \\
(.088)\end{array}$ & $\begin{array}{l}-.484 \\
(.291)\end{array}$ \\
\hline $\begin{array}{l}\text { Government } \\
\text { workplaces }\end{array}$ & $\begin{array}{l}.041^{*} \\
(.016)\end{array}$ & $\begin{array}{l}.027 \\
(.032)\end{array}$ & $\begin{array}{l}.012 \\
(.095)\end{array}$ & $\begin{array}{l}.060 \\
(.034)\end{array}$ & $\begin{array}{l}.080 \\
(.149)\end{array}$ \\
\hline Public schools & $\begin{array}{l}.003 \\
(.007)\end{array}$ & $\begin{array}{l}.010 \\
(.010)\end{array}$ & $\begin{array}{l}-.040 \\
(.042)\end{array}$ & $\begin{array}{l}.034 \\
(.022)\end{array}$ & $\begin{array}{l}.021 \\
(.090)\end{array}$ \\
\hline Private schools & $\begin{array}{l}-.001 \\
(.009)\end{array}$ & $\begin{array}{l}-.003 \\
(.013)\end{array}$ & $\begin{array}{l}-.089 \\
(.048)\end{array}$ & $\begin{array}{l}.005 \\
(.030)\end{array}$ & $\begin{array}{l}.156 \\
(.095)\end{array}$ \\
\hline Restaurants & $\begin{array}{l}.032 \\
(.025)\end{array}$ & $\begin{array}{l}.042 \\
(.049)\end{array}$ & $\begin{array}{l}-.021 \\
(.102)\end{array}$ & $\begin{array}{l}-.077 \\
(.054)\end{array}$ & $\begin{array}{l}-.104 \\
(.190)\end{array}$ \\
\hline Bars & $\begin{array}{l}-.026^{*} \\
(.010)\end{array}$ & $\begin{array}{c}-.092 * * \\
(.018)\end{array}$ & $\begin{array}{l}-.127^{*} \\
(.051)\end{array}$ & $\begin{array}{l}-.010 \\
(.024)\end{array}$ & $\begin{array}{l}.038 \\
(.097)\end{array}$ \\
\hline $\begin{array}{l}\text { Child care } \\
\text { centers }\end{array}$ & $\begin{array}{l}.002 \\
(.006)\end{array}$ & $\begin{array}{l}.006 \\
(.015)\end{array}$ & $\begin{array}{l}.008 \\
(.030)\end{array}$ & $\begin{array}{l}.016 \\
(.020)\end{array}$ & $\begin{array}{l}-.007 \\
(.061)\end{array}$ \\
\hline $\begin{array}{l}\text { Health care } \\
\text { facilities }\end{array}$ & $\begin{array}{l}.014 \\
(.026)\end{array}$ & $\begin{array}{l}.023 \\
(.048)\end{array}$ & $\begin{array}{l}.216 \\
(.108)\end{array}$ & $\begin{array}{l}.097 \\
(.069)\end{array}$ & $\begin{array}{l}-.320 \\
(.381)\end{array}$ \\
\hline $\begin{array}{l}\text { Recreational } \\
\text { facilities }\end{array}$ & $\begin{array}{l}-.002 \\
(.017)\end{array}$ & $\begin{array}{l}.105 * * \\
(.029)\end{array}$ & $\begin{array}{l}.195^{*} \\
(.078)\end{array}$ & $\begin{array}{l}.024 \\
(.039)\end{array}$ & $\begin{array}{l}-.057 \\
(.144)\end{array}$ \\
\hline $\begin{array}{l}\text { Cultural } \\
\text { facilities }\end{array}$ & $\begin{array}{l}-.016 \\
(.021)\end{array}$ & $\begin{array}{l}-.082 * \\
(.034)\end{array}$ & $\begin{array}{l}-.173^{*} \\
(.085)\end{array}$ & $\begin{array}{l}-.028 \\
(.055)\end{array}$ & $\begin{array}{l}.177 \\
(.178)\end{array}$ \\
\hline Public transit & $\begin{array}{l}.015 \\
(.013)\end{array}$ & $\begin{array}{l}-.033 \\
(.020)\end{array}$ & $\begin{array}{l}-.053 \\
(.056)\end{array}$ & $\begin{array}{l}.026 \\
(.021)\end{array}$ & $\begin{array}{l}-.058 \\
(.100)\end{array}$ \\
\hline Shopping malls & $\begin{array}{l}-.027 \\
(.024)\end{array}$ & $\begin{array}{l}-.080 \\
(.040)\end{array}$ & $\begin{array}{l}-.127 \\
(.093)\end{array}$ & $\begin{array}{l}-.039 \\
(.077)\end{array}$ & $\begin{array}{c}.437 \\
(.312)\end{array}$ \\
\hline $\mathrm{N}$ & 93375 & 14330 & 4507 & 8958 & 717 \\
\hline
\end{tabular}

Notes: * Significant at 5\%; ** significant at 1\%. Shown are estimated coefficients from OLS regressions (each column is a separate model). The dependent variable is the log of the number of cigarettes an individual reports she smoked in the past 30 days, and the sample is restricted to current smokers. Robust standard errors clustered at the state level are in parentheses. Observations are weighted with the CPS TUS self-response supplement weight. All samples include only indoor workers. Private sector workers and government workers are defined by respective class of worker codes in the CPS. School employees and eating and drinking place workers are defined by industry codes in the CPS. Bartenders are identified by occupation codes in the CPS; only bartenders in eating and drinking places are included here. Additional controls not reported (but available upon request) include: survey month, year, and state fixed effects, the real excise tax on a pack of cigarettes, and the individual and state demographic characteristics described in the text. 